\title{
REAL ESTATE MANAGEMENT IN MALAYSIAN PUBLIC SCHOOLS: DETERMINATION OF SUCCESS FACTORS
}

\author{
Shardy Abdullah, PhD \\ School of Housing, Building and Planning \\ Universiti Sains Malaysia \\ e-mail: shardy@usm.my \\ Mohd Nurfadzli Mat Nah, M.Sc. \\ School of Housing, Building and Planning \\ Universiti Sains Malaysia \\ e-mail:fazli1903@yahoo.co.uk \\ Arman Abdul Razak, M.Sc. \\ School of Housing, Building and Planning \\ Universiti Sains Malaysia \\ e-mail:arm_raz@usm.my
}

\begin{abstract}
Effective real estate management practice is needed to ensure that the property in Malaysia, including public schools, can be fully utilized. The purpose of this study is to identify the success factors of the real estate management of Malaysia's public schools. To achieve this aim, a questionnaire was developed as a research tool. The respondents involved were representatives of public schools and officers from the state education department offices (on the basis of whom the total population was calculated) in Pulau Pinang, Malaysia. The respondents were chosen using a random sampling method. The success factors of managing property in public schools were identified by Exploratory Factor Analysis (EFA), using the principals of component analysis, the t-test, Cronbach's alpha and mean analysis. The findings show that the majority of the respondents agreed that all of the listed 18 success factors within the 4 main factor groups as addressed in the survey are important for the efficient and effective improvement of real estate management, especially in Malaysian public schools.
\end{abstract}

Key words: real estate management, success factors, public schools, Malaysia.

JEL Classification: R39, I29.

Citation: Abdullah S., Nurfadzli Mat Nah M., Abdul Razak A., 2015, Real Estate Management in Malaysian Public Schools: Determination of Success Factors, Real Estate Management and Valuation, Vol. 23, No. 2, pp. 49-64.

DOI: 10.1515/remav-2015-0015

\section{Introduction}

In the field of real estate management, the need to effectively manage property, including both private and public buildings, seems to be pertinent. This is to ensure that property owners are able to organize activities and achieve their objectives. Furthermore, in both sectors, property has been progressively recognized as a strategic resource which can be exploited to meet organizational objectives (PHELPS 2011). Property, including land and buildings, is a valuable resource and acts as a 
medium of implementing various activities (BALCH 1994; MAZIAH 2001; ZAILAN, MAZIAH, 2002; ZAITON et al. 2008). As a real asset, property is affected by the performance of the underlying economy (In addition, it also plays an important role in the operational expenses of an organization as the second highest contributor following human resources) (REZANA, LIND 2006). Relatively speaking, the main issues of real estate management are building maintenance and physical development, which greatly affect the development of a nation. There are specific buildings provided by the government for the purpose of serving the needs and demand of the population, especially for educational enhancement. This scenario is evident in Malaysia, where the federal government's spending of public funds has been notable as a measure is sought to build and develop various real estates and facilities, especially for educational purposes, to improve the living standard of the community at large. The crucial need for appropriate and credible real estate management is understood by the government, as according to the Malaysian government (2009), real estate management is the very first phase where the provision of services, both directly or indirectly, can be managed and delivered.

Thus, proper studies on real estate management, specifically public assets, appear to be an opportune topic that warrants further discussion. Public assets are established for a very different reason than private properties. While private properties seemingly exist to facilitate economic and financial gains to the organization that owns the property, public buildings serve a more fundamental role, usually in meeting social needs and welfare. This is more evident in operational public buildings, such as schools, where the very intent of the buildings is to provide educational facilities in a conducive and effective manner. As public schools are not established to fulfil investment or financial purposes, the need for a more systematic and optimal form of real estate management is all the more evident and crucial. This is because these public assets do not generate sufficient revenue to finance their operation, maintenance and upkeep, which is a key distinguishing factor that divides the management of public and private property assets. It is often a common practice in real estate management of public assets to reschedule or even postpone maintenance activities in order to reduce public spending (MARKUS CHRISTEN et al. 2014). Even though extensive research has been carried out on the real estate management of private buildings, there is a significant dearth in studies, especially here in Malaysia, which focuses on the subject matter of real estate management from the perspective of public property assets.

The aim of this study, therefore, is to identify factors that contribute to the successful management of public school real estate in Malaysia. A literature review focusing on the experiences of public real estate management in other countries and on studies already conducted by other researchers marks the beginning of this paper. Subsequently, the work will highlight the methodology used in this study, before presenting the discussion of findings and results. Finally, conclusions derived from this research will be elaborated based on the significant observations and discoveries.

\section{Real estate management}

In a broad and general sense, the enhancement of the asset value of relevant properties as well as maximizing the generated income or return investment are the main objectives of real estate management (ARNOLD, JOHN 1989; SCARRETT 1983; EPLEY, RABIANSKI 1981). As a means of achieving this, Ching (1994) contends that real estate management practices can be applied to derive best performance in terms of financial and economic gains, social values, user satisfaction and asset optimization. Within the more specific realm of public buildings, the concerns are the ability to eliminate excess real estate assets, reduce operating costs and defer other related problems (ZAILAN 2001), as well as to eliminate wastage while preserving physical building functionality and integrity (ABD. RAHMAN 2004) by implementing effective real estate management.

ARNOLD and JOHN (1989) state that the enhancement of the asset value of a property is the main objective of real estate management. This is in accordance with SCARRETT (1983), who opined that income and the capital value of assets can be maximized through real estate management. It is therefore obvious that the key facets of real estate management comprise asset and capital value that should be leveraged by the stakeholders for the benefits of all parties. To that extent, it is evidently vital to ensure that the value of any property is maintained and enhanced by practicing real estate management so that investors or owners can achieve their targets. Again, this is parallel with EPLEY and RABIANSKI'S (1981) findings, who claimed that property owners can accomplish their objectives in investment by implementing management practices through professional property activities. CHING (1994) also mentioned that the application of real estate management practices in managing property 
should be utilized by any organization for the best performance. Best performance, in this context, refers to various aspects, including achievements in terms of user satisfaction, financial and economic benefits, optimization, social values and many other functions. The construction of public schools is not for financial or investment purposes, but rather more as an effort to meet social needs for educational purposes; buildings such as these are often referred to as operational buildings. Through a statement that was put forth by ABD. RAHMAN (2004), an efficient management system was linked with the implementation of real estate management practices. Such a system ensures maximum protection to the structures from becoming obsolete and guarantees returns from property.

Furthermore, ABD. RAHMAN (2004) also emphasized that the issue of waste can be handled through good maintenance and management by implementing real estate management practices. This view shows that the need to establish an efficient and effective management system for school buildings is the same as the importance of public school management practices. There is also a need to implement regulated and well-planned systematic maintenance. In fact, from the perspective of maintenance, such management practices can help to establish proper, safe and economical maintenance activities. Moreover, ZAILAN (2001) stated that, to eliminate excess real estate assets, reduce operating costs and defer related problems, efficient and effective real estate management should be implemented. This is in line with LYONS (2004), who states that effective and efficient real estate management will increase the level of service delivery and savings. Within the context of public schools, this would entail the assurance of an education delivery service that is protected from a less than optimal use of resources, including financial and human resources, equipment and others. From this point of view, the demand for well-managed school buildings that can provide educational services can be linked to the importance of real estate management practices for public schools.

A following focus is the need to establish systematic real estate management of public schoools, particularly regarding the aspects of quality control and assurance. According to MABEL (2002), quality management is a necessity. The purpose of quality management is to improve convenience, expertise and security while managing a property asset. Hence, a good learning environment within the schools, as well as other benefits, can be provided to the public, particularly students and faculty. In addition, public confidence on the quality of the educational services provided by the government can be gained. Meanwhile, SUMMERELL (2005) also argues in support of this notion, concluding in his study that the application of a real estate management process could help local government agencies establish the effective and efficient delivery of services. Steps to delivering the best service possible will subsequently lead to a greater quality of managing these properties.

According to the University of Leeds (2006), real estate management can improve managementrelated services, effectiveness, safety and accountability in managing finances. Moreover, by properly managing a project, the level of communication and the relationship between users and the management can be improved by preventing unnecessary ad-hoc and further alterations/additions to existing processes. Likewise, YOUNG (2007) and COX (2008) reiterate by saying that real estate management can improve financial management, responsibilities, and operations, as well as encourage savings. RENNISON (2007) goes as far as to say that management can solve any problem. COX (2008) also stresses the benefits of real estate management. According to him, management enables users to comfortably save money in the long run. Additionally, the importance of real estate management practices in public schools can be assessed on the basis of the experiences of others and opinions of governments of developed countries. For instance, the British government (2002) mentioned that real estate management is practiced to meet the demands of public services and to protect the people's rights. The Australian government (2003) also outlines several benefits that can be gained by practicing real estate management. Among these benefits are the fair and efficient division of tasks and improvement in coordinating the provision of services (thus higher employee satisfaction, an increase in the level of communication, higher efficiency and productivity, and savings.

Therefore, the implementation of real estate management practices is important in any organization, especially public institutions that own or utilize property assets to fulfil their operational requirements. Hence, it is essential to implement and practice real estate management in public schools. This is because there is a need for educational institutions to be properly managed and maintained in order to meet the objectives of public education set out by the government. Subsequently, the expectations of society in terms of conducive and comfortable learning environments can be fulfilled. 
The importance for public schools to practice real estate management is also based on other considerations. The Malaysian government (2009) stated that, as a part of an important aspect of financial management, property assets must be efficiently and effectively managed. Meanwhile, YAHYA (2007) mentioned that it is the government's responsibility to ensure that public infrastructure and buildings remain in good condition. Based on the above, it can be concluded that by implementing property asset management, public schools will experience many positive effects, so long as it is carried out in an efficient and effective manner.

\section{Success factors of real estate management}

For the effective and efficient improvement of managing government property assets, especially those of Malaysian public schools, there are several significant factors or elements that have to be considered and implemented by the authorized organizations/parties. The management should pay due attention to these factors and elements, as they are recognized as a catalyst that can enhance the level of efficiency and the effectiveness of managing property assets of public schools. According to ROCKART (1982), these catalyst factors are important aspects to management in ensuring that the objectives identified can be accomplished.

There have been numerous studies that identify certain key success factors that should be present within the implementation of real estate management activities, albeit mostly within the context of private property. Factors relating to the importance of set objectives as well as sufficient related resources have been espoused by researchers. Meanwhile, SIMONS (1993) discussed the factors that could be utilized when implementing the management of government property assets. These factors are namely: the identification of appropriate objectives, the use of a suitable IT-based database system, establishing specific property management work units manned by qualifed personnel, and the use of standardized management guidelines. His suggestions are supported by ZAILAN (2001), who posits that information resources are essential in practicing effective and efficient real estate management. Next, in terms of related resources, SCHULTZ (1971) emphasized the importance of human resources in real estate management, while the requirement of adequate financial resources was put forth by ABDUL HAMID (2002). Both of these resources are paramount to the development of real estate management in a more comprehensive manner. The above-mentioned researchers have clearly identified that elements of pre-determined objectives as well as the provision of adequate resources (encompassing human, information and financial resources) are catalysts that are clearly required for successful real estate management practices.

Another key factor is the implementation of a management system that it is active and flexible enough to accommodate future requirements, and characterized by a high level of monitoring and control (GIBSON 1994). This opinion is also shared by other researchers, namely ZAILAN (2001) and LI (1997), whereas Low (1999) refers to the need for effective leadership within real estate management activities and practices. To ensure real estate management is efficient and that it is effectively implemented, uniform management guidelines, which are consistent with the life cycle of buildings, should first be established. Low further noted the importance of effective communication to management. The same author also suggested that effective real estate management also requires effective leadership to expedite the effective implementation of related processes.

Factors regarding the granting of authority to lower level personnel, as well as an efficient decision-making process within organizations for better real estate management operations were also been put forth by YIP (2000). The author also stated that the granting of authority to subordinates enables the quality of service in real estate asset management to be improved more effectively. These rights are a concept of decision-making and responsibility placed on employees, who are the immediate implementors at the operational level, by the organization (YIP 2000). Other than these factors, the author also touched on three other factors that are able to enhance the efficiency and effectiveness of managing real estate, i.e. an effective information system, open communication and continuous training. MCENROE (2000), on the other hand, encourages organizational systems that have an open channel for communication, as well as a more flexible decision-making process that allows personnel who are directly involved in given activities to decide what is best. He also mentions the importance of implementing the "mind-setting" element to improve the effectiveness of decisionmaking processes related to real estate.

Mind-setting consists of three major components: perspective, which can be interpreted as the objectives in mind that are to be achieved; patience, signifying the process of implementation 
according to plan without ignoring certain processes; and appropriateness, which means selecting the right person within the management group. This is further expounded by KAGANOVA et al. (2001), who argued that real estate asset management should be carried out based on specific policies and procedures, and a clear understanding of roles and tasks. MUSIL (2006) and TREWIN (2006) also stated that effective and efficient real estate management can be implemented if a proper work ethic exists within an organization.

Meanwhile, SHAHIR (2007) and LATEEF (2008) identified several catalyst factors that can enhance the efficiency and effectiveness of government property asset management. These factors are clear management objectives, specialization in responsibility by reducing bureaucracy, skilled workers and effective leadership. In addition, he also stated that relevant property asset information should be more transparent and accessible, and should be contained in a single database. Similarly, Lateef (2008) believes that an operational procedure or clearer guidelines should be developed and standardized by the government to ensure that the problems that often occur in property asset management, particularly those pertaining to managing maintenance, can be mitigated and solved.

These studies essentially highlight the advantages of clearly designated roles and responsibilities coupled with sound management objectives and policies within organizations that have implemented real estate management systems or practices. It has been shown that the existence of these factors will go a long way in ensuring an improved real estate management process characterized by reduced bureaucracy, as well as better means to either mitigate or solve problems arising in maintenance management operations.

The need for skilled and qualified professionals who run real estate management systems in organizations is yet another factor which is deemed crucial. SHARDY et al. (2011) also suggest that the involvement of qualified professionals with knowledge and expertise in property asset management is needed to enable management to be implemented more efficiently and effectively. This is further supported by KRUMM (2001), who preceded the former authors in attesting to the importance of such personnel on example of a well-managed real estate management practice, which reflected that these professionals are needed in the construction, maintenance and management of property. Other factors that have been identified to be relevant in ensuring the success of real estate management are the need for systematic evaluation and a process for measuring performance (KISHK et al. 2005), which come hand in hand with an incentives and initiatives system (MANAF, MARZUKI, 2009) in place within the organizational governance structure.

In terms of factors that are pertinent to a more effective real estate management service delivery process, GIBLER et al. (2002) promote the use of new technology, while de SILVA and RANASINGHE (2010) propose the inclusion of supporting achievement procedures and strategic goals. A report published by the government of the United State of America (2009) sums up all these factors by stressing that the efficiency and effectiveness of property asset management can be enhanced by improving the policy and the level of accountability, providing a clear understanding of the objectives or goals of management, developing an effective information collection system, and increasing the level of cooperation between departments related to property as well as increasing their knowledge, skills and expertise in the field of real estate management. KISHK et al. (2005), on the other hand, mentions that evaluation and the measurement of performance are critical in real estate management; hence, the importance of providing and implementing incentives and initiatives as a means of rewarding excellence (MANAF, MARZUKI, 2009). According to Gibler et al. (2002), the use of new technology could increase the level of services delivered to the public, with real estate management being no exception. De SILVA and RANASINGHE (2010) state that the most important task to be undertaken to enhance the efficiency and effectiveness of real estate management is the development of procedures supporting achievement and strategic goals. Based on the above deliberations, real estate management success factors for public schools can be divided into seven main themes. Table 1 presents the general categories these factors fall into, as well as their source of origin.

Based on Table 1, the most frequently discussed success theme is that revolving around policy and guidelines. This aspect is indeed important in determining the successful implementation of public school real estate management practices, as it acts as a very fundamental guide for those who are involved in executing real estate management practices in public schools. The second most frequently discussed themes are those concerning a clear management objective and adequate resources. Both of these themes are important to public schools. Without a clear management objective, real estate 
management activities would not be able to be conducted precisely as there would not be a definitive pre-determined target or achievement to be reached. The theme focusing on the need for resources (including human, information and financial resources) clearly indicates that without the adequate allocation of these resources, the implementation of the planned real estate management activities at public schools will surely be affected by hindrances, delays or even failures. In addition to the above, the leadership theme has also been commonly identified by previous researchers as being among the factors that contribute to the successful implementation of the real estate management practice. This theme clearly requires the practices of implementing real estate management in public schools to be headed by those who serve top management functions within these schools. This is because such people are usually capable of influencing or steering other parties in such a way that ensures that real estate management practices are implemented systematically and effectively.

Table 1

\begin{tabular}{|c|c|c|c|c|c|c|c|}
\hline \multirow[b]{2}{*}{$\begin{array}{l}\text { AUTHORS } \\
\text { (YEAR) }\end{array}$} & \multicolumn{7}{|c|}{ SUCCESS FACTOR THEMES OF REAL ESTATE MANAGEMENT } \\
\hline & $\begin{array}{l}\text { Policy and } \\
\text { Guidelines }\end{array}$ & Leadership & $\begin{array}{c}\text { Clear } \\
\text { Objectives }\end{array}$ & Resources & $\begin{array}{l}\text { Information } \\
\text { Technology }\end{array}$ & $\begin{array}{c}\text { Monitoring } \\
\text { and } \\
\text { Control }\end{array}$ & $\begin{array}{c}\text { Incentives } \\
\text { and } \\
\text { Initiatives }\end{array}$ \\
\hline SIMONS (1993) & $\sqrt{ }$ & & $\sqrt{ }$ & $\sqrt{ }$ & $\sqrt{ }$ & & \\
\hline ZAILAN (2001) & & & $\sqrt{ }$ & & & & \\
\hline $\begin{array}{l}\text { SCHULTZ } \\
(1971)\end{array}$ & $\sqrt{ }$ & $\sqrt{ }$ & & $\sqrt{ }$ & & & \\
\hline GIBSON (1994) & & & & & & $\sqrt{ }$ & \\
\hline BOND (1994) & & & & & & $\sqrt{ }$ & \\
\hline LI (1997) & $\sqrt{ }$ & $\sqrt{ }$ & & & & & \\
\hline Low (1997) & & $\sqrt{ }$ & & & & & \\
\hline YIP $(2000)$ & $\sqrt{ }$ & $\sqrt{ }$ & $\sqrt{ }$ & $\sqrt{ }$ & $\sqrt{ }$ & & \\
\hline $\begin{array}{l}\text { MCENROE } \\
(2000)\end{array}$ & $\sqrt{ }$ & $\sqrt{ }$ & $\sqrt{ }$ & $\sqrt{ }$ & & & \\
\hline $\begin{array}{l}\text { KAGANOVA } \\
(2001)\end{array}$ & $\sqrt{ }$ & & $\sqrt{ }$ & & & & \\
\hline SHAHIR (2007) & & $\sqrt{ }$ & $\sqrt{ }$ & $\sqrt{ }$ & & & \\
\hline LATEEF (2007) & $\sqrt{ }$ & & $\sqrt{ }$ & & & & \\
\hline $\begin{array}{l}\text { SHARDY, } \\
\text { ARMAN (2008) }\end{array}$ & & $\sqrt{ }$ & & $\sqrt{ }$ & & & \\
\hline KRUMM (2001) & & & & $\sqrt{ }$ & & & \\
\hline $\begin{array}{l}\text { Government } \\
\text { of the United } \\
\text { States of } \\
\text { America } \\
\text { (2008) }\end{array}$ & $\sqrt{ }$ & & $\sqrt{ }$ & $\sqrt{ }$ & & & \\
\hline $\begin{array}{l}\text { KISHK et al. } \\
(2005)\end{array}$ & $\sqrt{ }$ & & & & & & \\
\hline $\begin{array}{l}\text { MANAF, } \\
\text { MARZUKI } \\
(2009)\end{array}$ & & & & & & & $\sqrt{ }$ \\
\hline $\begin{array}{l}\text { GIBLER et al. } \\
(2002)\end{array}$ & & & & & $\sqrt{ }$ & & \\
\hline $\begin{array}{l}\text { DE SILVA, } \\
\text { RANASINGHE } \\
(2010)\end{array}$ & $\sqrt{ }$ & & & & & & \\
\hline TOTAL & 10 & 7 & 8 & 8 & 3 & 2 & 1 \\
\hline
\end{tabular}

Success factor themes of real estate management. Source: own study.

Apart from the four themes mentioned above, Table 1 also lists three other success factor themes, namely: information technology, which indicates that the chances for the successful implementation of public school real estate management can be increased by the adaptation of information technology applications that are relevant to their current needs; monitoring and control, which refers to the need 
for establishing an approach which is objective in manner, as well as consistent in assessing the performance of real estate management activities in public schools; and finally, incentives and initiatives, which relates to the existence of a reward system as well as the need to respond in a creative and proactive way to further enhance the implementation of the real estate management process in public schools.

Thus, through the sufficient discussion and detailed descriptions of the factors that may improve property asset management, it was determined that some vital factors must to be initially addressed and implemented in an effort to enhance property asset management practices, especially those of public schools. Among the factors that are deemed applicable by the present research, are the development of appropriate procedures, effective leadership, communication skills, as well as other factors that had previously been elaborated on in this paper.

\section{Research methodology}

The aim of the research was to determine the factors that contribute to successful real estate management, particularly that of Malaysian public schools. This research was conducted using a questionnaire survey. A pilot test was performed as dictated by THABANE et al. (2010) to ensure that the targeted research requirements can be achieved. The questionnaire was divided into 2 main parts. The first part concerned the respondents' background, while the second part focused on success factors prevalent in property asset management, particularly the management of public schools. The survey made use of the Likert scale answer range, with "strongly disagree" denoted by the number "1", and "strongly agree" denoted by a "5". The research was conducted in Pulau Pinang, Malaysia. As shown below, Table 2 lists the total population of the respondents within the study area.

Table 2

Population of respondents

\begin{tabular}{lc}
\hline Respondents & Population \\
\hline State education department's office & 6 \\
\hline Public schools & 395 \\
\hline
\end{tabular}

Source: own study.

The two groups of respondents chosen for this study were made up of relevant individuals from the state education department (denoted as Group 1) and public schools (denoted as Group 2). The rationale behind the inclusion of respondents from the state education department's offices is that these departments are also directly involved in public school real estate management, especially in monitoring and overseeing the management processes conducted by the public schools, a job function stipulated by the Malaysian Ministry of Education (2011). Doing so also ensured a more balanced response from all the parties involved in the real estate management process. Since the total population for the first group of respondents is too small, no sampling method was undertaken for this population category. As such, all six of the state education department's offices were selected to participate in the research. Meanwhile, a random sampling method was implemented for the second population of public schools. This method is considered suitable if there are similarities within the population (SEKARAN 1992). The sample was selected based on YAMANE (1967 as cited in Israel 1992). Further explanation is provided by the following equation:

$$
\mathrm{n}=\mathrm{N} /\left[1+\mathrm{N}\left(\mathrm{e}^{2}\right)\right]
$$

where:

n - sample size,

$\mathrm{N}$ - population size,

e - level of precision.

With a $95 \%$ confidence level and $\pm 5 \%$ level of precision, the total number of public schools in Pulau Pinang (395) was used as the basis for the calculations. 199 respondents were determined as the appropriate sample size from the public schools. However, in the event that the return of survey forms turned out to be poor, 250 questionnaires were distributed. Face-to-face interviews were also conducted in some cases during the data collection process with the management and staff of selected public schools. Before the findings of the research were elaborated on in the discussion section of this 
work, the collected data were analyzed using Cronbach's alpha analysis, t-test analysis, frequency analysis (descriptive) and factor analysis. Figure 1 shows the methodology framework for the research.

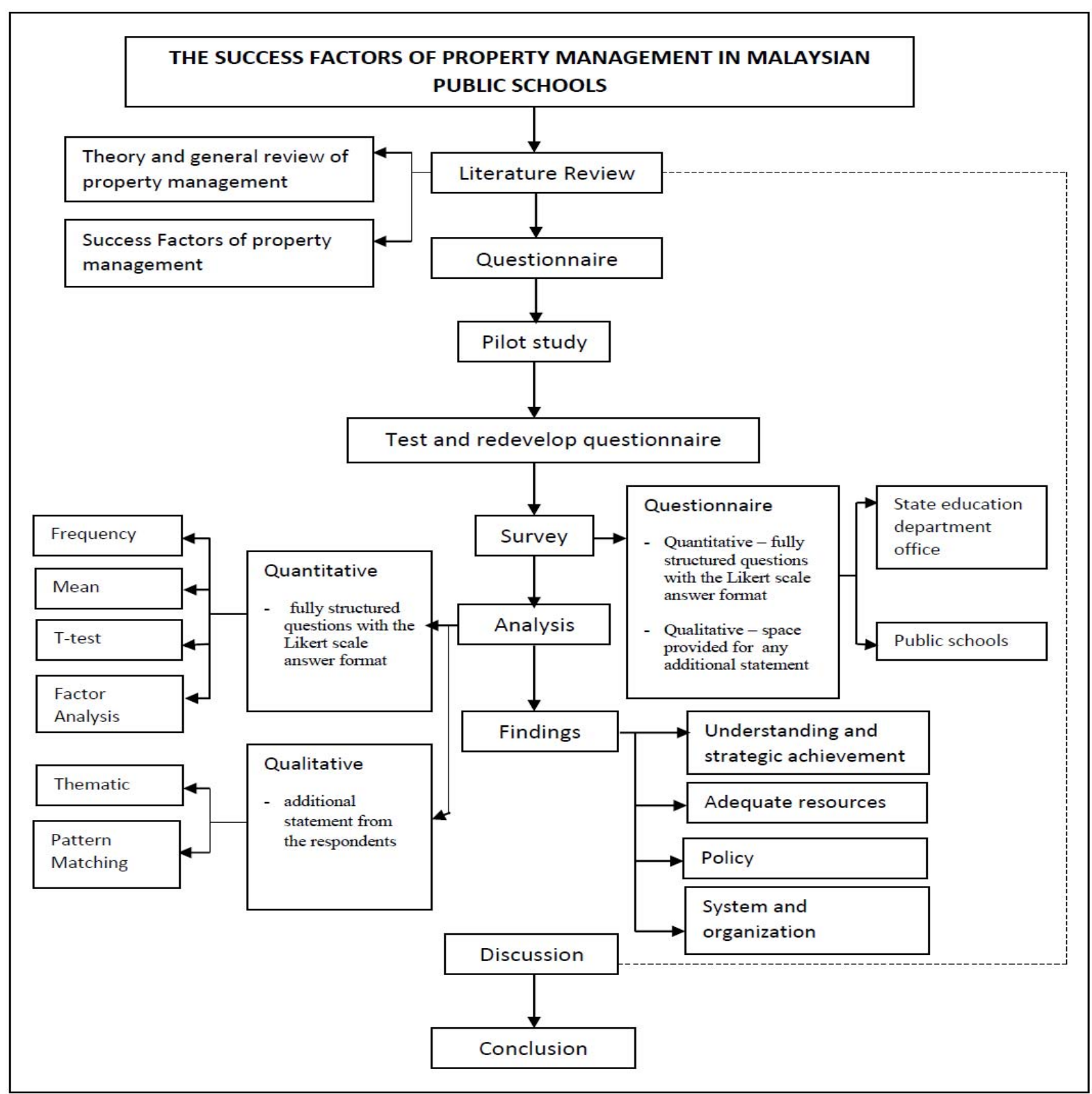

Fig. 1. Framework of study methodology. Source: own study.

\section{Research findings}

\subsection{Profile of respondents}

Only 213 out of 250 survey forms distributed were completed and returned. Of these, 150 forms were filled in by respondents from elementary schools, 58 by ones from secondary schools, with the remaining 5 forms completed by staff of state education department offices. A list containing the detailed background of the respondents can be found in Table 3 .

Based on data from Table 3, it was shown that most of the respondents were principals, amounting to 86 respondents. Senior assistants represented the second highest number of respondents, with a total of 72 completed questionnaires. Administrative assistants (12), designated teachers (41) and other staff (2) made up the rest of the respondents. The majority of the respondents (97) held a bachelor's degree qualification, while 88 respondents received a formal education up to diploma level. The rest of the respondents were high school graduates (26) and 1 respondent each had either a post graduate/PhD or professional qualifications. The low number of post-graduate/ $\mathrm{PhD}$ respondents and especially those holding professional qualifications is largely due to the fact that this level of 
qualification is generally not required within the civil service sector. The majority of respondents (134) had 5 or more years' experience in real estate management, while 39 respondents had 1 to 3 years' experience in real estate management. 21 of the respondents had been involved in real estate management for 3 to 5 years, while 19 respondents had less than a year's worth of experience.

Table 3

Respondents' profiles

\begin{tabular}{lcc}
\hline Profile of respondents & $\begin{array}{c}\text { Number of } \\
\text { respondents }\end{array}$ & Rank \\
\hline Types of organizations & 150 & 1 \\
\hline Elementary school & 58 & 2 \\
\hline High school & 5 & 3 \\
\hline State education department & & 1 \\
\hline Job position of respondents & 86 & 2 \\
\hline Principal & 72 & 3 \\
\hline Senior assistant & 41 & 4 \\
\hline Task designated teacher & 12 & 5 \\
\hline Administrative assistant & 2 & 1 \\
\hline Other & & 2 \\
\hline Highest level of education & 97 & 3 \\
\hline Bachelor's Degree & 88 & 4 \\
\hline Diploma & 26 & 4 \\
\hline High school graduate & 1 & \\
\hline Post-graduate degree/PhD & 1 & 1 \\
\hline Professional qualification & & 2 \\
\hline Involvement in real estate management & 134 & 3 \\
\hline$>5$ years & 39 & 4 \\
\hline$>1$ - 3 years & 21 & \\
\hline$>3$ - 5 years & 19 & \\
\hline$<1$ year & & \\
\hline
\end{tabular}

Source: own study.

\subsection{Success factors of real estate management (t-test and Cronbach's alpha analyses)}

Before subjecting the collected data to frequency and factor analysis, t-test analysis and Cronbach's alpha analysis were performed to aid their interpretation. The purpose of the t-test was to check whether there were any significant gaps in the answers provided by the two groups of respondents (Pallant, 2005), while Cronbach's alpha analysis was performed to test the validity of the prepared questions.

Table 4

T-test and Cronbach's alpha analyses on the success factors of real estate management

\begin{tabular}{|c|c|c|c|c|c|c|}
\hline Group & Mean & Variance & $\mathbf{t}$ & df & $\begin{array}{c}\text { Significance } \\
\text { value }\end{array}$ & $\begin{array}{c}\text { Alpha } \\
\text { Cronbach value }\end{array}$ \\
\hline 1 & 73.19 & 9.36 & -1.654 & 211 & 0.100 & 0.946 \\
\hline 2 & 80.20 & 9.55 & & \\
\hline
\end{tabular}

Source: own study.

Table 4 depicts the results obtained from the t-test and Cronbach's alpha analysis performed on data regarding the success factors of real estate management, particularly in public schools. Based on the t-test, the results show that slight differences can be observed between Group $1(\mathrm{M}=73.19$, $\mathrm{SD}=9.36)$ and Group $2(\mathrm{M}=80.20, \mathrm{SD}=9.55)$. This outcome also indicates that no major dissimilarities exist between the two groups. Cronbach's alpha analysis resulted in a value of 0.946 , 
which denotes high reliability as this value exceeds the par value of 0.7 as suggested by NunALLY (1978).

Hence, from the outcomes of both analyses, it was concluded that all the survey questions could be fully utilized and all the data/information from both groups could be compiled and subjected to further analysis.

\subsection{Success factors of real estate management (frequency and factor analyses)}

Table 5 illustrates the results of the mean analysis of the success factors of real estate management in the corresponding public schools. The total mean for Table 5 is $x=4.07$. The analysis shows that the majority of the respondents were in agreement that the listed success factors are important to property asset management in their schools. The most significant factor recognized by most of the respondents was "understanding roles and responsibility", with a mean value of 4.21. The second most significant factors were shown to be "information resources" and "effective leadership", each of which was characterized by a mean value of 4.18. There were also several other factors which scored mean values of at least 4.00 and above, denoting their importance as success factors. Among these other factors are "knowledge of skill and expertise" and "human resources", which are usually considered to be pertinent success factors in the management field. Although these factors were not ranked relatively high, their importance was still acknowledged. The remaining factors received mean values of less than 4.00, ranking as follows: incentive and initiative (3.97), financial resources (3.92) and building lifecycle procedures, and strategy, policy and guidelines (3.90 each).

Table 5

Mean analysis of success factors of real estate management

\begin{tabular}{lccc}
\hline Success Factors & $\bar{X}$ & Scale & Rank \\
\hline Understanding roles and responsibility & 4.21 & Agree & 1 \\
\hline Information resources & 4.18 & Agree & 2 \\
\hline Effective leadership & 4.18 & Agree & 2 \\
\hline Empowerment & 4.17 & Agree & 3 \\
\hline Proper work ethic & 4.16 & Agree & 4 \\
\hline Organizational structure & 4.14 & Agree & 5 \\
\hline Valuation and assessment of performance & 4.14 & Agree & 5 \\
\hline Effective communication & 4.13 & Agree & 6 \\
\hline Appropriateness and effectiveness of information management & 4.10 & Agree & 7 \\
\hline Detailed information on property assets & 4.08 & Agree & 8 \\
\hline Appropriateness and effectiveness of information system & 4.08 & Agree & 8 \\
\hline Support procedure on strategic management & 4.06 & Agree & 9 \\
\hline Knowledge of skill and expertise & 4.01 & Agree & 10 \\
\hline Human resources & 4.00 & Agree & 11 \\
\hline Incentive and initiative & 3.97 & Agree & 12 \\
\hline Financial resources & 3.92 & Agree & 13 \\
\hline Strategy, policy and guidelines & 3.90 & Agree & 14 \\
\hline Building life-cycle procedures & 3.90 & Agree & 14 \\
\hline Average & 4.07 & Agree & - \\
\hline
\end{tabular}

Source: own study.

Using component analysis, the 18 success factors of real estate management were subjected to exploratory factor analysis (EFA). Through this analysis, all the success factors were classified into several groups to identify the key factors in successfully managing the property assets of Malaysian public schools. As recommended by PALLANT (2005), the value needed to conduct factor analysis is 0.3. Barlett's test of sphericity, which showed statistical significance with a Kaiser-Mayer-Olkin value of 0.8, exceeded the recommended value of 0.6 (PALLANT, 2005; COAKES and STEED, 2003). The principal component analysis conducted in this study shows four factors with Eigen values exceeding 1 , indicating respective percentages of variance of $53.45 \%, 8.21 \%, 7.44 \%$ and $5.89 \%$ as shown in Table 6. As denoted in Table 6, the first key factor is understanding and strategic achievement, indicating that understanding roles and responsibility, effective communication, valuation and assessment of 
performance, empowerment, and procedures supporting strategic management all fall into a similar trend. The second key factor of resources contains four components, i.e.: financial resources, human resources, incentive and initiative, and information resources. Next, the third key factor is policy, indicating that a proper work ethic, building life-cycle procedures, appropriateness and effectiveness of information management, and strategy, policy and guidelines also fall within a similar trend. The last key factor of "organization and system" was connected with five elements, i.e. detailed information on the property asset, appropriateness and effectiveness of the information system, effective leadership, organizational structure, and skill and expertise.

Table 6

Factor analysis of success factors of real estate management

\begin{tabular}{|c|c|c|c|c|c|}
\hline \multirow{2}{*}{ Success factors } & \multicolumn{4}{|c|}{ Factor loading } & \multirow{2}{*}{ Commonality } \\
\hline & 1 & 2 & 3 & 4 & \\
\hline \multicolumn{6}{|c|}{ Factor 1: Understanding and strategic achievement } \\
\hline $\begin{array}{l}\text { Understanding roles and } \\
\text { responsibility }\end{array}$ & 0.811 & & & & 0.826 \\
\hline Effective communication & 0.797 & & & & 0.788 \\
\hline $\begin{array}{l}\text { Valuation and assessment of } \\
\text { performance }\end{array}$ & 0.784 & & & & 0.769 \\
\hline Empowerment & 0.689 & & & & 0.788 \\
\hline $\begin{array}{l}\text { Procedure supporting strategic } \\
\text { management }\end{array}$ & 0.603 & & & & 0.834 \\
\hline \multicolumn{6}{|c|}{ Factor 2: Adequate resources } \\
\hline Financial resources & & 0.878 & & & 0.873 \\
\hline Human resources & & 0.809 & & & 0.852 \\
\hline Incentive and initiative & & 0.545 & & & 0.588 \\
\hline Information resources & & 0.545 & & & 0.590 \\
\hline \multicolumn{6}{|c|}{ Factor 3: Policy } \\
\hline Proper work ethic & & & 0.790 & & 0.796 \\
\hline Building life-cycle procedures & & & 0.704 & & 0.855 \\
\hline $\begin{array}{l}\text { Appropriateness and effectiveness of } \\
\text { information management }\end{array}$ & & & 0.676 & & 0.733 \\
\hline Strategy, policy and guidelines & & & 0.584 & & 0.631 \\
\hline \multicolumn{6}{|c|}{ Factor 4: System and organization } \\
\hline $\begin{array}{l}\text { Detailed information on the property } \\
\text { asset }\end{array}$ & & & & 0.706 & 0.787 \\
\hline $\begin{array}{l}\text { Appropriateness and effectiveness of } \\
\text { the information system }\end{array}$ & & & & 0.669 & 0.804 \\
\hline Effective leadership & & & & 0.663 & 0.721 \\
\hline Organizational structure & & & & 0.654 & 0.615 \\
\hline Skill and expertise & & & & 0.652 & 0.646 \\
\hline Eigen values & 9.621 & 1.478 & 1.339 & 1.060 & \\
\hline Variance $(\%)$ & 53.448 & 8.210 & 7.438 & 5.889 & \\
\hline Cumulative variance (\%) & 53.448 & 61.658 & 69.096 & 74.889 & \\
\hline Cronbach's alpha & 0.910 & 0.861 & 0.851 & 0.855 & \\
\hline
\end{tabular}

Source: own study.

\section{Discussion}

Based on the carried out analyses, no significant differences were been noted between Group 1 and Group 2. This scenario proves that the discussions on real estate management success factors as explained by both groups are rather similar and follow similar course, especially in terms of the level and implementation of procedures in the real estate management of the public schools, despite the fact that they essentially come from different types of organizations. In short, there are four main factors, 
explained in greater detail in the following subchapters, that must be regarded to increase the effectiveness and standard of competency of public schools in Malaysia, i.e:

1. Understanding and strategic achievement factor,

2. Resource factor,

3. Policy factor, and

4. Organization and system factor.

\subsection{Understanding and strategic achievement factor}

According to the outcomes of the research, the first critical factor that leads to enhancement in the level of proficiency and efficiency in the real estate management of public schools is the understanding and strategic achievement factor. The respondents clearly agreed that successful real estate management begins at the strategic level, which includes the need for proper and effective communication, as well as a strong understanding of roles and responsibilities. The respondents also affirmed that there is a significant requirement for empowerment and an established support structure to complement the strategic direction set by top management. This indicates that the current mindset has ceased to view real estate management as not a part of the top management function and rather merely as an operational function that receives attention when things have gone wrong (CHUA SJL et al. 2015). This finding is also in line with studies conducted by KAGANOVA et al. (2001), MuSIL (2006), YIP (2000), and DE SILVA and RANASINGHE (2010). In addition, YIP (2000) asserts on the importance of communication and empowerment in any management, primarily in real estate management, while de Silva and RANASINGHE (2010) affirm that the application of procedures to support strategic achievement in determining the success of management is significant under the purview of real estate management itself.

\subsection{Resource factor}

Another success factor that can be associated with the capability to enhance the real estate management practice is the resource factor. In this context, the ability to ensure adequate resources has been linked with this factor, and this was acknowledged by the survey respondents. Resources are clearly needed if any aspect of management is to be conducted effectively, and are all the more important in the real estate management of public schools. The respondents demonstrated that they feel that adequate and relevant resources are important if a public school is to be managed well, especially in terms of building maintenance and the implementation of real estate management core activities. This feedback from the respondents, particularly the need for sufficient financial and human resources, are similar to the findings of other scholars, particularly in studies of ZAILAN (2001), BECKER (1964), Delaney and Huselid (1996), Schultz (1971), SomboOn (2006), AbDul HAMid (2002), MANAF and MARZUKI (2009).

\subsection{Policy factor}

The third factor that was attested by most of the respondents as a driver of success is the policy factor. This is clearly illustrated by the percentage this factor obtained, exceeding the majority value in the case of all four success elements. The significant support received for this factor is due to the importance of its underlying assumptions that clear and established guidelines, policies and predetermined strategies will enable an effective form of real estate management to be carried out. Another item that was strongly stressed by the respondents is the efficient management of information as management practices do rely on an appropriate management system to be in place for the implementation of activities. This outcome is indeed congruent with the findings of earlier studies, released by YIP (2000), TREWIN (2001), Li (1997), DE SILVA and RANASINGHE (2010).

\subsection{Organization and system factor}

The last factor that was affirmed by the majority of the respondents is the organization and system factor. In this case, the percentage of all the success items comprising this factor surpassed the majority value. The results obtained have verified that the respondents agree as to the need for establishing a systematic organizational structure with a key focus on leadership as well as skill and expertise. Systematic organization is also understood as having teams with specific roles, functions and tasks. Well-structured and close-knit teams will undoubtedly allow the organization to succeed in meeting its objectives, as demonstrated by research undertaken on the attribution of team members 
(MARTINKO et al. 2011). With such an organizational structure, the respondents feel that public school real estate management can be enhanced and improved, as the structure of the organization will, in itself, assist management processes. This last factor is also consistent with previous studies of Low (1999), SHAHIR (2007), SHARDY et al. (2011), KRUMM (2001), YIP (2000), and the Government of the United States of America (2009).

Thus, based on the comparison between previous findings and the outcome of this research, it can be concluded that the above-mentioned success factors must be considered to improve the effectiveness and competence level of real estate management in public schools. The findings of this study can be fully utilized by making changes or restructuring the governance structure of the parties involved in managing public schools, namely, the ministry of education, state education departments, and the top management of public schools itself. Restructuring, in this context, involves efforts to establish a specific department, section or task unit that is given the responsibility to plan, implement, monitor and measure the achievements of real estate management practices conducted in these public schools. The creation of such entities has to be undertaken in a precise and detailed manner, with personnel made up of workers who possess sufficient and relevant knowledge, skills and experience in the field of real estate management. This is to assure that the identified success factors are given due consideration to be utilized or implemented, and finally monitored to enable real estate management practices in public schools to be enhanced in terms of their effectiveness and efficiency.

\section{Conclusion}

This paper discusses the findings of a survey conducted in Pulau Pinang, Malaysia, encompassing 213 respondents involved in managing public school property assets. The aim of this survey is to determine the prevalent success factors in the management of public school property assets. The results of this study indicate that most of the respondents agree as to the importance of all of the success factors that were addressed in the questionnaire utilized in this research. Of these 18 success factors, the study also confirms four key factors which are necessary for managing property assets in public schools. These four key factors were identified and derived using factor analysis.

The study has the potential to be further developed for future research. By doing so, suitable improvements can be made in the real estate management practice, especially where public schools are concerned. In addition, other developing countries with similar management structures can utilize the findings of the present study in exploring or implementing real estate management practices to increase their efficiency and effectiveness, and ultimately become sustainable.

\section{References}

AbD. Rahman, M.N., 2004, Pengurusan Harta Tanah Komersial dan Awam, Leeds Publication, Petaling Jaya.

AbDUl HAMID, M. I., 2000, An Introduction to Property Marketing, Universiti Teknologi Malaysia. Article source at http:/ / eprints.utm.my/4495/1/propertymarketing.pdf. 2 November 2013, 2.45 a.m.

Akimov, A., Stevenson, S. And Zagonov, M., 2015, Public Real Estate and the Term Structure of Interest Rates: A Cross-Country Study, Journal of Real Estate Finance and Economics, DOI $10.1007 /$ s11146-014-9492-x.

ARNOld L. R. AND JoHn R. T., 1989, The Acquisition and Disposition of Real Estate by Corporate Executives: A Survey, Journal of Real Estate Research, American Real Estate Society, Vol. 4(3), pp. 67-80.

Australia Government, 2003, Property Management Australian National Audit Office. Audit Report No.19 2003-04. Business Support Process Audit. Australia. Article source at http://www.anao.gov.au/ /media/Uploads/Documents/2003\%2004_audit_report_19.pdf. 10 October 2013, 9.00 a.m.

BALCH, W.F., 1994, The integrated approach to property and facilities management, Facilities, Vol. 12 No. 1, pp. 17-22.

BECKER, G.S., 1964, Human Capital. New York: National Bureau of Economic Research.

British Government, 2002, Government Service Delivery Risk Management Accounting Reporting Guidelines. Capital Asset Management Framework. Government of British. Article source at http:/ / www.fin.gov.bc.ca/tbs/camf_guidelines.pdf. 6 Jan. 2014, 4.43 pm.

CHING, C. H., 1994, Property management in English local authorities: a corporate approach to the management of operational property, unpublished PhD thesis, University of Liverpool, Liverpool. 
CHuA SJL, Ali AS, AliAs AB., 2015, Implementation Of Analytic Hierarchy Process (AHP) Decision Making Framework For Building Maintenance Procurement Selection: Case Study Of Malaysian Public Universities, Eksploatacja i Niezawodnosc - Maintenance and Reliability, 17 (5): 7-18.

COAKES, S. J. \& STEED, L.G., 2003, SPSS Analysis without Anguish Version 11.0 for Windows, John Wiley \& Sons Australia, Ltd.

COx, H., 2008, The importance of property management. Article in Enzine Article. 12 March $2008 . \quad$ Article Source at http:/ / EzineArticles.com/1041836.

De SILVA, N. AND RANASINGHE, M., 2010, Maintainability Risks of Condominiums in Sri Lanka, Journal of Financial Management of Property and Construction, Vol. 15, No. 1, pp. 41-60.

DELANEY, J. T. AND HuSELID, M. A., 1996, The impact of human resource management practices on perceptions of organizational performance. The Academy of Management Journal, 39(4), pp. $949-969$.

EPLEY, D.R. AND RABIANSKI, J., 1981, Principle of Real Estate Decisions, Addison-Wesley, Reading, MA.

GIBSON, V., 1994, Strategic Property Management - How Can Local Authorities Develop a Property Strategy. Property Management (UK), Vol. 12 No. 3, pp. 9-14.

Gibler, K.M., BlACK, R.T. AND MOON, K.P., 2002, Time, Place, Space, Technology and Corporate Real Estate Strategy, The Journal of Real Estate Research, Vol. 24, No. 3

Government of United States of America, 2009, Readiness and emergency management for schools. U.S. Department of Education. United States of America. Article retrieved at http://rems.ed.gov/index.php?page=publications_Lessons_Learned. 6 November 2013, 7.30 p.m.

IsRAEL, G. D., 1992, Sampling the Evidence of Extension Program Impact. Program Evaluation and Organizational Development, IFAS, University of Florida. PEOD-5. October.

Kaganova, O., TiAn, V. AND Undeland, C., 2001, Learning How to Be Efficient Property Owners and Accountable Governments: The Case of Kyrgyzstan's Cities, Public Administration and Development, Vol. 21, No. 4, pp. 333-341.

KISHK, M., POlLOCK, R., ATTA, J. AND POWER, L., 2005, A structured model for performance assessment in property management. Journal of Financial Management of Property and Construction. Great Britain. Dec. 2005, Vol. 10, No. 3, pp. 159 - 169.

KRUMM, P. T. M. M., 2001, History of real estate management from a corporate perspective. Facilities; Jul/Aug 2001; No. 19, 276.

LATEEF, O.A., 2008, Building Maintenance Management in Malaysia. Journal of Building Appraisal. Universiti Islam Antarabangsa. Kuala Lumpur. Vol. 4 No. 3, pp. 207-214.

LI, L.H., 1997, Property Management in China: Opportunities And Problem. Property Management. Vol. 15, No. 1, pp. 6-11.

Low, G.T., 1999, Preparation of aspiring principals in Singapore: a partnership model, paper presented at the Conference on Professional Development of School Leaders, Centre for Educational Leadership, Hong Kong: University of Hong Kong.

LyONS, M., 2004, Towards Better Management of Public Sector Assets: A Report to the Chancellor of the Exchequer. Crown. Norwich. Dec. 2004.

MABEL, C. C. C., 2002, Quality Property Management and Your Daily Life, First Regional Conference on Private Building Management. Hong Kong 2002. Article source at http:/ / www.buildingmgt.gov.hk/file_manager/en/documents/18.pdf. 7 Feb. 2014, 3.35 a.m.

Malaysian Government, 2009, Dasar pengurusan aset kerajaan. Malaysia. Article source at http:/ / www.jmm.gov.my/files/DPAK\%28Versi2023Mac2009\%29.pdf. 24 Dec. 2013, 7.30 a.m.

Malaysian Ministry of Education, 2011, Source at http://www.moe.gov.my/ ?id=45\&act=division\&cat=BPPA, 3 Apr. 2014, 10.50 a.m.

MALE, S., 2007, Improving Property Asset Management in the Central Civil Government Estate. Organised by the Institution of Engineering and Technology Asset Management Network, University of Leeds, Stevenage, Herts SGI 2AY, UK. 9 October 2007. Article source at http:/ / ieeexplore.ieee.org/stamp/stamp.jsp?arnumber $=04450009$.

MANAF, A.B. AND MARZUKI, N.A., 2009, The Success of Malaysian Local Authorities: The Roles of Personality and Sharing Tacit Knowledge. International conference on administrative development: Towards excellence in public sector performance. King Faisal Hall, Riyadh, Kingdom of Saudi Arabia. Nov. 1-4, 2009

MARKuS CHRISTEN, Jules SCHROEDER AND HOLGer WALlBAuM, 2014, Evaluation of Strategic Building Maintenance and Refurbishment Budgeting Method Schroeder, International Journal of Strategic Property Management, 18:4, 393-406. 
Martinko, M.J., Harvey, P. AND DAsborough, M.T., 2011, Attribution theory in the organizational sciences: A case of unrealized potential, Journal of Organizational Behavior, 32, 144-149.

MAZIAH, I., 2001, FM practice in Malaysia: Where are We Heading? Facilities Management Seminar. Kuala Lumpur. 7 Apr. 2001.

MCENROE, K., 2000, Relocation and Expansion: Using Processes and Information to Deliver Success, Journal of Corporate Real Estate, Vol. 3 No. 2, pp. 115-120.

Musil, T.A., 2006, Critical Issues in Corporate Real Estate: Developing a Better Understanding of Public Sector Project Impact Analysis Practices, Journal of Corporate Real Estate, Vol. 8, No. 3, pp. 151 - 162.

NunALlY, J.C., 1978, Psychometric Theory. New York. McGraw Hill.

PALLANT, J., 2005, A step by step guide to data analysis using SPSS for windows (Version 12), SPSS survival manual. $2^{\text {nd }}$ ed. Australia: Allen \& Unwin.

PHELPS, A., 2011, Municipal property asset management - a comparative study of UK and Russia, International Journal of Strategic Property Management, 15:4, 416-437.

RENNISON. B. W., 2007, Historical discourses of public management in Denmark: Past emergence and present challenge. Management \& Organizational History. Sage Publications.Vol. 2(1): 5-26.

ReZAnA, M. AND Lind, H., 2006, Real Estate Management in Swedish Public Sector - Focused Healthcare Real Estate in Stockholm County Council, Master of Science Thesis. Royal Institute of Technology Department of Real Estate and Construction Management Division of Building and Real Estate Economics. Sweden.

ROCKART, J.F., 1982, The changing role of the information systems executive: a critical success factors perspective', Sloan Management Review, Vol. 23 No. 1, Fall, pp. 3-13.

SCARrETT, D., 1983, Pengurusan Harta, Dewan Bahasa dan Pustaka, Kuala Lumpur, Translation - Ismail Omar (1993).

SCHUlTZ, T.W., 1971. Investments in Human Capital. New York, NY: Macmillan.

SEKARAN, U., 1992, Research methods for Business a Skill Building Approach. $2^{\text {nd }}$ ed. New York: John Wiley \& Sons.

SHAHRIR, A.S., 2007, Critical Issues in Managing Government's Assets E Facilities In Malaysia. National Asset and Facility Management. Malaysia

Shardy AbDullah AND ARMAn AbDul RAZAK, 2008, The Development of Property Manager Competency Model: A Brief from Literature Review. Proceedings of the International Real Estate Research Symposium (IRERS) 2008. National Institute of Valuation. Kuala Lumpur. pp. 337-351

Shardy, A., Arman A.R., MoHd Hanizun, H. AND Mohd NAJIB, S., 2011, Managing Government Property Assets: The Main Issues From the Malaysian Perspective. Journal of Techno-Social, ISSN 22298940 Vol. 3 No. 1 Apr. 2011.

SIMONS, R.A., 1993, Public Real Estate Management - Adapting Corporate Practice to the Public Sector. The Journal of Real Estate Research, Fall 1993, pp. 639-653.

SOMBOON, K., 2006, Human capital development in the international organization: rhetoric and reality, Journal of European Industrial Training, 30(9), pp. 721-734.

SUMMERELL, R., 2005, Implications of real-property asset management, The CPA Journal, Vol. 75 No. 10.

Thabane, L., MA, J., CHU, R., CHENG, J., IsmailA, A., Rios, L. P., et al., 2010, A tutorial on pilot studies: the what, why and how. BMC Medical Research Methodology, 10(1), 1.

TREWIN, D., 2006, A Project Management Framework that has Worked for the ABS, In Project Management and Organisational Change. John Wanna (ed.). Canberra: ANU Press.

Utusan Malaysia, (2007). Budaya Selenggara Aset. Utusan Malaysia Online - Rencana.htm, 13 August 2007. Article retrieved at http://www.utusan.com.my/ utusan/info.asp?y=2007\&dt=0813\&pub=Utusan_Malaysia\&sec=Rencana\&pg=re_01.htm. 25 Mar. 2014, 10.00 a.m.

YIP, J. S. L., 2000, Quality service success - property management development to empowerment: a Hong Kong analysis. Journal of Structural Survey.Vol. 18. No. 4. pp. 148-154

YounG, G.T., 2007, Federal Real Property Asset Management. Corporate Partner Advisory Group Research. AGA CPAG Research Series. America, Mar. 2007. No. 8.

ZAILAN, M.I., 2001, The management of public property in Malaysia, paper presented at the International Conference FIG Working Week 2001, Seoul, 6-11 May. 
ZAILAN, M.I. AND MAZIAH, I., 2002, A review on performance measurement approaches in property management, paper presented at the International Real Estate Research Symposium (IRERS) 2002, Kuala Lumpur.

Zaiton, A., Stanley, M., Alastair, A. And James R. W., 2008, Corporate Real Estate Strategy: A Conceptual Overview. Journal of Real Estate Literature, 16(1): 3-22. 